\title{
PENGARUH KEMITRAAN TERHADAP KINERJA USAHA MIKRO DAN KECIL TAHU DI INDONESIA
}

\author{
Rizky Ariesty Fachrysa Halik ${ }^{1}$, Amzul Rifin ${ }^{2}$, dan Siti Jahroh ${ }^{3}$ \\ 1)Program Magister Sains Agribisnis, Sekolah Pascasarjana, Institut Pertanian Bogor \\ 2)Departemen Agribisnis, Fakultas Ekonomi dan Manajemen, Institut Pertanian Bogor \\ Jl. Kamper Wing 4 Level 5 Kampus IPB Dramaga Bogor, Indonesia \\ 3)Sekolah Bisnis, Institut Pertanian Bogor \\ Jl. Raya Pajajaran, Kampus IPB Gunung Gede Bogor, Indonesia \\ e-mail: 1)rizkyariesty28@gmail.com
}

(Diterima 24 Mei 2019/Disetujui 24 Mei 2019)

\begin{abstract}
A partnership is a form of cooperation that is needed to be done for business development so that it can be globally competitive. With the existence of a partnership, it can improve the ability of small businesses through capital support and professional resource training to increase business income and continuity. In Indonesia, tofu business is one of the micro and small businesses that have the potential to be developed. To improve business performance, it is necessary to collaborate among tofu businesses and large businesses or state-owned enterprises. The purpose of this study was to analyze the effect of partnerships and other factors on the performance of the tofu business in Indonesia. Tofu businesses can be grouped into two categories, namely partner and non-partner businesses. To estimate the performance of tofu businesses in Indonesia, multiple linear regression method was used. The data used in this study were collected from the Central Bureau of Statistics and the Ministry of Cooperatives and SMEs, in which 237 tofu businesses were taken as samples. The results showed that partnership had a positive and significant impact on tofu businesses income. Besides, business life, raw material cost, labour force and marketing allocation also positively significant affected tofu businesses income. However, the level of education, the age of the entrepreneur, the number of tools used, business capital, training, sales distribution, and cooperatives did not significantly affect tofu businesses income.
\end{abstract}

Keywords: business performance, micro and small enterprises, multiple regression, partnership, tofu

\begin{abstract}
ABSTRAK
Kemitraan merupakan sebuah bentuk kerjasama yang perlu dilakukan untuk pengembangan usaha agar mampu berdaya saing global. Dengan adanya kemitraan, dapat meningkatkan kemampuan usaha kecil melalui dukungan modal serta pelatihan sumber daya yang professional agar dapat meningkatkan pendapatan usaha dan kelanjutan sebuah usaha. Di Indonesia, usaha tahu merupakan salah satu usaha mikro dan kecil yang berpotensial untuk dikembangkan. Demi meningkatkan kinerja usaha tahu, perlu dilakukan kerjasama antara usaha tahu dengan usaha besar atau BUMN. Tujuan dari penelitian ini adalah untuk menganalisis pengaruh kemitraan dan faktor lain terhadap kinerja usaha tahu di Indonesia. Usaha tahu dikelompokkan ke dalam dua kategori, yaitu usaha yang bermitra dan usaha non mitra. Metode analisis yang digunakan adalah analisis linier berganda. Data yang digunakan diperoleh dari Badan Pusat Statistik (BPS) dan Kementerian Koperasi dan UKM dengan sampel sebanyak 237 usaha mikro dan kecil tahu. Hasil penelitian menunjukkan bahwa kemitraan berpengaruh positif signifikan terhadap pendapatan usaha. Selain itu, umur usaha, biaya bahan baku, jumlah tenaga kerja dan alokasi pemasaran juga berpengaruh positif signifikan pendapatan usaha. Namun, tingkat pendidikan, umur pengusaha, jumlah alat yang digunakan, modal usaha, pelatihan, distribusi penjualan, serta koperasi secara signifikan tidak mempengaruhi pendapatan usaha.
\end{abstract}

Kata kunci: kemitraan, kinerja usaha, regresi berganda, tahu, usaha mikro dan kecil 


\section{PENDAHULUAN}

Kemitraan merupakan suatu bentuk kerjasama yang perlu dilakukan untuk pengembangan sebuah usaha agar mampu berdaya saing global. Kemitraan memiliki tujuan yaitu untuk meningkatkan kemampuan usaha kecil agar menjadi kuat dan berkembang melalui dukungan modal serta pelatihan sumber daya yang profesional dan terampil agar dapat meningkatkan pendapatan perusahaan dan kelanjutan sebuah usaha. Berdasarkan data yang diperoleh dari Badan Pusat Statistik (BPS) bahwa perusahaan kecil dan perusahaan besar yang telah menjalin kerjasama (kemitraan) masih sekitar 20 persen dari total usaha yang ada di Indonesia. Oleh sebab itu, kementerian Koperasi dan UMKM berupaya mendorong kemitraan antara usaha kecil dan usaha besar karena kemitraan diyakini akan meningkatkan kontribusi UMKM sebagai tulang punggung perekonomian nasional. Hal ini dibuktikan oleh kontribusi usaha mikro, kecil dan menengah (UMKM) pada pertumbuhan produk domestik bruto (PDB) pada tahun 2017 yaitu sebesar 62 persen. Berdasarkan data tersebut menunjukkan bahwa usaha mikro dan kecil mempunyai peranan penting dalam mewujudkan tujuan pembangunan negara sekaligus sebagai sektor yang mampu diandalkan untuk mendukung ketahanan ekonomi.

Salah satu usaha kecil yang potensial untuk dikembangkan ialah usaha pembuatan tahu. Jika usaha tahu dijalankan dengan serius, diduga dapat menguntungkan bagi pengusaha karena konsumen tahu sangat luas, mencakup semua strata sosial. Tahu tidak hanya dikonsumsi oleh masyarakat kelas bawah dan menengah, tetapi juga oleh masyarakat kelas atas. Ini terlihat dari masuknya produk tahu di pasar swalayan. Selain itu, hampir semua tempat makan biasa hingga restaurant mewah, memiliki tahu sebagai salah satu menu makanan dengan berbagai inovasi. Hal ini tidak terlepas dari industri pengolahan tahu yang saling bekerjasama dengan rumah makan atau warung sebelum sampai ke konsumen akhir. Usaha tahu saat ini masih tergolong usaha kecil yang masih perlu pengembangan usaha. Maka dari itu dengan adanya kegiatan kemitraan ini, industri tahu dapat berkembang dan menjadi usaha skala besar. Potensi "win-win" dalam kemitraan menimbulkan banyak argumen mengenai efisiensi dalam mempertahankan hubungan kemitraan, dikarenakan perusahaan yang menjalankan kemitraan dapat mengakses jaringan yang lebih luas, menggabungkan sumber daya dan keahlian serta berbagi praktik yang baik untuk menyelesaikan tugas-tugas tertentu (Louise 2011). Manfaat yang sinergis ini membentuk sebuah keunggulan yang dikenal dengan istilah "keunggulan kolaboratif" sesuai dengan pendapat Huxham dan Vangen (2005).

Terdapat beberapa usaha tahu di Indonesia yang melakukan kerjasama dengan berbagai jenis kemitraan guna meningkatkan kinerja usahanya. Akan tetapi, berdasarkan data BPS (2015), jumlah usaha yang tidak bermitra masih lebih banyak dibandingkan usaha tahu yang bermitra. Padahal dengan terjalinnya kerjasama (kemitraan) dapat memperkuat dan mengembangkan usaha itu sendiri, sesuai dengan tujuan kemitraan juga yaitu memperoleh keuntungan (Fletcher 1987). Tujuan utama dari kemitraan adalah untuk meningkatkan daya saing bisnis untuk semua rekan mitra (Rudberg dan Olhager 2003). Kunci keberhasilan dari usaha mikro dan kecil dalam persaingan pasar domestik maupun global adalah membangun kemitraan dengan usaha besar. Pengembangan usaha mikro dan kecil akan lebih mudah dilakukan jika melibatkan usaha besar. Usaha mikro dan kecil dapat mengeskpor produknya melalui perantara usaha besar yang telah menjadi eksportir (Pamungkas 2006). Dengan begitu, disimpulkan bahwa tujuan utama adanya kemitraan usaha yaitu untuk meningkatkan daya saing dan kinerja usaha untuk semua rekan mitra. Keberhasilan usaha adalah tujuan utama dalam menjalankan sebuah usaha. Kinerja usaha dapat diukur menggunakan indikator peningkatan income (pendapatan), sales (penjualan), output (produk yang dihasilkan), produktivitas, biaya, penerimaan la- 
yanan, kecepatan reaksi atau berubah, pencapaian standar kualitas atau reaksi pelanggan (Amstrong, 2004). Terdapat beberapa faktor yang memengaruhi kinerja usaha mikro dan kecil, Hati dan Irawati (2017) dalam penelitiannya membagi faktor internal yang memengaruhi kinerja usaha menjadi empat aspek yaitu aspek sumber daya manusia, aspek keuangan, aspek teknis dan operasional serta aspek pasar dan pemasaran. Masing-masing aspek memiliki indikator seperti pada aspek sumber daya manusia, indikatornya yaitu tingkat pendidikan formal, jiwa kepemimpinan, pengalaman atau lama berusaha serta motivasi dan keterampilan. Pada aspek keuangan, indikatornya yaitu modal pribadi, modal pinjaman, tingkat keuntungan dan membedakan pengeluaran. Pada aspek teknis dan operasional, indikatornya yaitu bahan baku yang tersedia, kapasitas produksi, tersedia mesin dan peralatan, teknologi modern dan pengendalian kualitas. Sedangkan pada aspek pasar dan pemasaran, indikatornya yaitu permintaan pasar, penetapan harga bersaing, kegiatan promosi, saluran distribusi dan wilayah pemasaran. Adapun keanggotaan koperasi dan kemitraan juga secara langsung berpengaruh terhadap kinerja usaha.

Selain meringankan masalah sosial, beberapa ahli mengatakan bahwa kemitraan usaha dapat memberikan manfaat khusus bagi mitra. Manfaat untuk usaha yaitu mendapatkan keunggulan kompetitif, membangun kepercayaan dalam komunitas, mengelola persepsi eksternal dengan meningkatkan reputasi publik, meningkatkan daya tarik kepada calon karyawan serta meningkatkan hubungan pemangku kepentingan (Porter dan Kramer 2002). Hal tersebut sesuai dengan simpulan penelitian Mohr (1994) yang mengatakan bahwa sebuah usaha memutuskan untuk menjalin sebuah kemitraan dengan alasan untuk mencapai tujuan perusahaan dan dimotivasi untuk mendapatkan keunggulan kompetitif di pasar. Saat ini usaha tahu, utamanya usaha tahu yang belum bermitra mengalami beberapa kesulitan dalam usaha, diantaranya yaitu kesulitan dalam permodalan, kesulitan memperoleh bahan baku, kesulitan dalam memasarkan produk, kesulitan memperoleh tenaga kerja yang terampil, serta kesulitan dalam memperoleh mesin yang baik. Adapun kesulitan memperoleh bahan baku dan permodalan yang paling banyak dialami oleh usaha tahu di Indonesia, khususnya pada usaha tahu yang belum bermitra. Oleh karena itu, pemerintah sangat mendorong agar lebih banyak usaha tahu yang menjalin kemitraan dengan usaha besar, karena selain dapat meminimalkan kesulitan yang dialami, juga dapat mengembangkan kinerja usaha mikro dan kecil di Indonesia. Berdasarkan uraian dari latar belakang dan perumusan masalah tersebut, maka dapat dirumuskan permasalahan dalam penelitian ini adalah bagaimana pengaruh kemitraan dan faktor lainnya terhadap kinerja usaha tahu di Indonesia?.

\section{METODE}

\section{PENGUMPULAN DATA DAN ANALISIS}

Sumber data yang digunakan dalam penelitian ini adalah data sekunder yang merupakan data hasil survey Industri Mikro dan Kecil (IMK) dari kelompok Klasifikasi Baku Lapangan Indonesia (KBLI), usaha pengolahan kedelai menjadi tahu yang diperoleh dari Badan Pusat Statistik, dengan kode KBLI 10392. Jumlah unit usaha yang digunakan dalam penelitian ini yaitu sebanyak 237 unit usaha tahu. Usaha tahu yang menjadi sampel ini merupakan usaha tahu yang bermitra dan non mitra.

\section{METODE ANALISIS DATA}

Penelitian ini menggunakan alat analisis regresi linear berganda dengan menggunakan software STATA 11, untuk menjawab tujuan penelitian yaitu menganalisis pengaruh kemitraan dan faktor lainnya terhadap kinerja usaha tahu di Indonesia. Kinerja UMK tahu diukur dengan pendapatan usaha, yang mana pendapatan usaha merupakan penghasilan yang diperoleh dari aktivitas usaha yang biasa 
dikenal dengan penjualan. Pada penelitian ini, pendapatan diukur melalui selisih penerimaan dari hasil penjualan dikurangi biaya produksi yang dikeluarkan. Hal ini berdasarkan pendapat dari Macro et al. (2005) yang menyatakan bahwa keberhasilan kinerja usaha dapat dilihat dari adanya keberlangsungan dan pertumbuhan usaha, penambahan tenaga kerja, peningkatan keuntungan dan pendapatan Adapun faktor-faktor yang memengaruhi kinerja usaha terbagi dalam beberapa aspek, menurut Purwaningsih dan Pajar (2015) dan Munizu (2010), yaitu aspek sumber daya manusia (SDM), aspek keuangan, aspek teknis produksi dan operasi, aspek pemasaran serta aspek peranan lembaga terkait, yang kemudian akan disesuaikan dengan ketersediaan data dari Survei IMK tahun 2015. Berdasarkan studi pustaka tersebut maka ditentukan variabel-variabel yang memengaruhi kinerja usaha tahu berdasarkan dari kelima aspek tersebut yang terdiri dari aspek sumber daya manusia meliputi tingkat pendidikan formal, pengalaman atau lama berusaha, umur pengusaha dan pelatihan; aspek keuangan meliputi modal pribadi dan modal dari pihak lain; aspek teknis produksi dan operasional meliputi bahan baku yang tersedia, jumlah tenaga kerja dan jumlah alat yang digunakan; aspek pasar dan pemasaran meliputi saluran distribusi, wilayah pemasaran dan kemitraan; dan aspek peranan lembaga terkait meliputi koperasi. Pemilihan variabel-variabel tersebut berdasarkan literatur dan ketersediaan data. Adapun pemilihan model pada persamaan ini menggunakan model logaritma natural dengan pertimbangan yaitu untuk menyamakan satuan. Berikut adalah model yang digunakan dalam penelitian ini.

\begin{tabular}{|c|c|}
\hline LnPDPTN = & $\begin{array}{l}\mathrm{a}_{0}+\mathrm{a}_{1} \text { LnUMRUS }_{\mathrm{i}}+ \\
\mathrm{a}_{2} \text { LnTKPEND }_{\mathrm{i}}+\mathrm{a}_{3} \text { LnUMRPU }+ \\
+\mathrm{a}_{4} \mathrm{DPLT}_{\mathrm{i}}+\mathrm{a}_{5} \text { DMOD }_{\mathrm{i}}+ \\
\mathrm{a}_{6} \text { LnPBB }_{\mathrm{i}}+\mathrm{a}_{7} \text { LnALAT }_{\mathrm{i}}+ \\
\mathrm{a}_{8} \text { LnTKRJ }_{\mathrm{i}}+\mathrm{a}_{9} \text { DPER }_{\mathrm{i}}+ \\
\mathrm{a}_{10} \text { DPED }_{\mathrm{i}}+\mathrm{a}_{11} \text { DLPEM }_{\mathrm{i}}+ \\
\mathrm{a}_{12} \text { DKOPR }_{\mathrm{i}}+\mathrm{a}_{13} \text { DKMTRN }_{\mathrm{i}}+ \\
\varepsilon_{\mathrm{t}}\end{array}$ \\
\hline
\end{tabular}

Keterangan:

LnPDPTN : Nilai pendapatan usaha (Rp/bulan)

$\mathrm{a}_{0} \quad:$ Koefisien model pendapatan

$\alpha_{1-} \alpha_{13} \quad$ : Koefisien yang mempengaruhi produktivitas $1,2, . .13$

UMRUS : Umur usaha beroperasi secara komersial (tahun)

TKPEND : Lama pendidikan yang ditempuh pengusaha (tahun)

UMRPU : Umur pemilik usaha (tahun)

DPLT : Dummy keikutsertaan pengusaha dalam pelatihan ( $1=$ ya, $0=$ tidak $)$

DMOD : Dummy modal yang digunakan (1 $=$ modal pribadi, $0=$ modal lain)

PBB : Nilai pemakaian bahan baku (Rp)

ALAT : Jumlah alat yang digunakan dalam usaha (buah)

TKRJ : Jumlah tenaga kerja (orang)

DPER : Dummy kategori 1 distribusi penjualan $(1=$ perusahaan, $0=$ lainnya

DPED : Dummy kategori 2 distribusi penjualan $(1=$ pedagang, $0=$ lainnya)

DLPEM : Dummy alokasi pemasaran ( $1=\mathrm{Di}$ dalam kota, $0=$ Di luar kota)

DKOPR : Dummy keikutsertaan usaha dalam koperasi $(1=$ ya, $0=$ tidak $)$

DKMTRN : Dummy usaha memiliki mitra $(1=$ ya, $0=$ tidak)

I : Jumlah responden $(1,2, . . \mathrm{i})$

$\varepsilon_{\mathrm{t}} \quad:$ Error term

Terdapat beberapa langkah yang perlu dilakukan sebelum melakukan analisis estimasi pada kedua model. Langkah pertama, yaitu membuat persamaan model dengan variabel-variabel terpilih. Langkah kedua, yaitu melakukan pengujian diagnostik untuk memastikan tidak terdapat masalah dalam model atau model telah memenuhi syarat pengujian asumsi klasik (uji multikolinearitas, uji heteroskedastisitas dan uji normalitas) sebelum dianalisis menggunakan regresi linier berganda. Selanjutnya, ketika model telah memenuhi syarat uji asumsi klasik, dilakukan analisis hasil estimasi berdasarkan nilai Rsquared, signifikansi model (Uji F dan Uji-t), serta nilai koefisien tiap variabel. 


\section{HASIL DAN PEMBAHASAN}

\section{PENGARUH KEMITRAAN TERHADAP KINERJA USAHA MIKRO DAN KECIL TAHU DI INDONESIA}

Kemitraan merupakan jalinan kerjasama antara dua pihak atau lebih dalam jangka waktu tertentu sesuai kesepakatan kedua belah pihak untuk mencapai tujuan masingmasing, dengan menggunakan prinsip saling menguntungkan, saling memperkuat dan saling membesarkan. Akan tetapi, saat ini usaha mikro kecil banyak mengalami hambatan dalam mengembangkan usahanya, khususnya pada usaha tahu. Berdasarkan data Badan Pusat Statistik (BPS) tahun 2015, usaha mikro dan kecil yang mengalami kesulitan dalam menjalankan usahanya yaitu sebesar 73,96 persen. Kesulitan utama yang dirasakan oleh usaha mikro dan kecil adalah kesulitan modal usaha sebesar 38,84 persen, kesulitan pemasaran hasil usaha sebesar 25,00 persen dan kesulitan bahan baku sebesar 22,9 persen. Kemitraan yang terjalin antara usaha-usaha tahu di Indonesia dengan usaha lain jumlahnya masih sedikit, hanya sekitar 11 persen usaha tahu yang menjalin kemitraan dengan usaha lain dengan jumlah usaha sebanyak 26 unit usaha tahu,sedangkan usaha tahu yang tidak menjalin kemitraan sebesar 89 persen dengan jumlah usaha sebanyak 211.

Pada hasil estimasi model persamaan pendapatan (Tabel 1), variabel dummy kemitraan memiliki nilai p-value 0,037 , yang mana nilai tersebut lebih kecil dari taraf nyata 5 persen. Hal ini menunjukkan bahwa kemitraan memiliki pengaruh positif yang signifikan terhadap pendapatan. Selain itu, variabel dummy kemitraan memiliki nilai koefisien sebesar 0,4596. Hal ini menunjukkan apabila usaha tahu menjalin kemitraan dengan usaha lain, maka akan meningkatkan pendapatan usaha. Sudibyo (1997) mengungkapkan bahwa kemitraan menjadi suatu hal yang penting dilakukan antara usaha kecil dan usaha besar untuk meningkatkan kemajuan usaha kecil, terutama untuk mengecilkan kesenjangan antara usaha kecil dengan usaha besar. Kemajuan usaha kecil salah satunya dapat dilihat dari tingkat pendapatannya. Kinerja usaha menyangkut tujuan dari intern usaha, jika ingin meningkatkan kinerja usaha, maka yang perlu diperhatikan bagaimana mencapai tujuan intern usaha. Sesuai dengan pendapat Porter (1980) yang menyatakan bahwa jika suatu usaha ingin mencapai tujuan intern maka usaha tersebut akan bergantung pada mitra usahanya. Dengan adanya mitra usaha dapat meningkatkan penyebaran informasi, transaksi yang efisien, proses teknologi dan inovasi, penghematan biaya, memperpendek waktu pengembangan produk, manajemen logistik dan program pemasaran lainnya seperti dapat melakukan promosi bersama.

Tabel 1. Hasil Estimasi Model Kinerja Usaha Tahu di Indonesia

\begin{tabular}{lr}
\hline \multicolumn{1}{c}{ Variabel } & Koefisien \\
\hline Umur usaha & $0,2675^{* * *}$ \\
Tingkat pendidikan & 0,1294 \\
Umur pengusaha & $-0,2574$ \\
Bahan baku & $0,5855^{* * *}$ \\
Jumlah alat & 0,0371 \\
Jumlah tenaga kerja & $0,6553^{* * *}$ \\
Dummy modal usaha & 0,0820 \\
Dummy pelatihan & 0,3551 \\
Distribusi penjualan ke perusahaan & 0,6056 \\
Distribusi penjualan ke pedagang & 0,0070 \\
Dummy alokasi pemasaran & $0,3936^{* *}$ \\
Dummy koperasi & 0,2165 \\
Dummy kemitraan & $0,4596^{* *}$ \\
Konstanta & 5,1283 \\
Sig, Uji F & 0,0000 \\
R-squared & 0,6217 \\
\hline Keterangan: & \\
$* * *$ signifikan pada taraf nyata 1 persen & \\
** = signifikan pada taraf nyata 5 persen &
\end{tabular}

Kemitraan yang terjalin antara usaha tahu di Indonesia dengan usaha lainnya terbagi atas empat jenis kemitraan, yaitu kemitraan bahan baku, kemitraan modal, kemitraan pemasaran dan kemitraan alat/ mesin. Jenis kemitraan yang paling banyak dilakukan antara usaha kecil dan usaha lainnya ialah kemitraan bahan baku yaitu sebanyak $46 \%$ dari total usaha tahu di Indonesia. Adapun usaha mitra bahan baku ini ialah koperasi dan pedagang kedelai. Dengan adanya mitra bahan baku dapat memudahkan para pelaku usaha tahu untuk 
memperoleh bahan baku, yang mana saat ini kesulitan kedua yang dialami usaha tahu utamanya usaha tahu yang belum bermitra, yaitu memperoleh bahan baku. Kebanyakan usaha yang tidak bermitra kesulitan memperoleh bahan baku karena harganya yang mahal dan langka. Bahan baku memiliki peran penting dalam peningkatan pendapatan usaha tahu, karena jika bahan baku sulit diperoleh makan produksi akan terhambat bahkan cenderung pengusaha berhenti memproduksi, akibatnya penjualan pun akan terhambat sehingga berdampak pada pendapatan usaha tahu.

Kemitraan pemasaran merupakan jenis kemitraan kedua paling banyak dilakukan antara usaha kecil dan usaha besar (lainnya). Adapun rekan mitra (usaha lainnya) disini yaitu para pedagang produk olahan tahu. Dalam hal ini, usaha tahu lebih banyak memasarkan produknya di dalam kota dibanding luar kota. Pada hasil estimasi model pendapatan menunjukkan bahwa alokasi pemasaran di dalam kota dapat meningkatkan kinerja usaha. Disamping itu, pada usaha non mitra, pemasaran menjadi salah satu kesulitan ketiga paling banyak yang dihadapi oleh usaha tahu. Jika usaha tahu memutuskan untuk menjalin kemitraan dalam bidang pemasaran dengan pedagang olahan tahu, maka kesulitan pemasaran dapat diminimalkan.

Adapun uang atau modal yang menjadi jenis kemitraan antara usaha tahu dengan usaha lain atau rekan mitra. Hanya sedikit usaha tahu yang bermitra dalam bentuk modal atau uang. Hal ini dikarenakan Hampir seluruh usaha tahu yang bermitra menggunakan modal sendiri. Selain itu, berdasarkan data BPS terdapat sekitar 62 persen usaha tahu yang bermitra maupun non mitra menggunakan modal sendiri, akan tetapi masih ada sekitar 38 persen usaha tahu yang masih menggunakan modal dari sumber lain. Adapun sumber modal lain yang paling banyak digunakan yaitu pinjaman dari Bank, kemudia beberapa usaha tahu juga menggunakan pinjaman dari perorangan dan pinjaman dari keluarga.
Selanjutnya, peralatan yang digunakan dalam usaha juga menjadi salah satu jenis kemitraan antara usaha tahu dan rekan mitra walaupun jumlah usaha yang bermitra hanya sedikit. Hal ini bisa saja karena mesin atau alat yang digunakan dalam pembuatan tahu tidak sulit diperoleh, jadi beberapa usaha tahu memang telah memiliki mesin atau alat sendiri. Adapun mesin dan alat yang pada umumya digunakan dalam usaha tahu diantaranya mesin penggiling, diesel, kompor, dynamo giling, pencetak tahu, penggorengan, baskom, panci dan loyang.

Selain itu, pada Tabel 2, berdasarkan hasil uji beda rata-rata pendapatan usaha tahu yang bermitra dan usaha tahu non mitra, diperoleh hasil yang menunjukkan bahwa terdapat perbedaan rata-rata pendapatan usaha tahu yang bermitra dan non mitra pada taraf nyata 5 persen. Adapun nilai rata-rata pendapatan usaha tahu yang bermitra lebih besar dibandingkan nilai rata-rata pendapatan usaha tahu non mitra dengan selisih sebesar Rp 12.345.568. Sehingga dapat disimpulkan bahwa dengan adanya kemitraan dapat meningkatkan pendapatan usaha tahu. Adapun hasil penelitian ini sesuai dengan penelitian dari Suryana (2014) yang menyatakan bahwa variabel kinerja usaha kecil yang meliputi aspek keuangan dan non keuangan dipengaruhi oleh variabel kemitraan.

Tabel 2. Hasil Uji Beda Rata-Rata Pendapatan Kelompok Usaha Tahu di Indonesia

\begin{tabular}{lc}
\hline $\begin{array}{c}\text { Kelompok Usaha } \\
\text { Tahu }\end{array}$ & $\begin{array}{c}\text { Rata-rata } \\
\text { pendapatan (Rp) }\end{array}$ \\
\hline Bermitra & 23.707 .663 \\
Non mitra & 11.362 .094 \\
Selisih & $12.345 .568^{* *}$ \\
\hline
\end{tabular}

Keterangan:

** = signifikan pada taraf nyata 5 persen

\section{PENGARUH FAKTOR LAINNYA TERHADAP KINERJA USAHA MIKRO KECIL TAHU DI INDONESIA}

Hasil estimasi model pendapatan dapat dilihat pada Tabel 1. Dari hasil diperoleh variabel umur usaha, bahan baku, jumlah 
tenaga kerja, dan alokasi pemasaran terbukti memiliki pengaruh yang signifikan terhadap pendapatan usaha tahu di Indonesia pada taraf nyata 1 persen dan 5 persen.

Berdasarkan hasil estimasi model pendapatan diketahui bahwa jumlah tenaga kerja memiliki koefisien paling besar. Pada Tabel 1, nilai koefisien variabel jumlah tenaga kerja sebesar 0,6553, yang menunjukkan bahwa semakin banyak tenaga kerja yang digunakan pada usaha tahu maka pendapatan yang diperoleh juga akan maksimal. Usaha tahu masuk dalam kategori pekerjaan pada sektor informal, yang mana sektor ini tersebar di berbagai daerah, jumlahnya tidak terbatas dengan berbagai jenis aktivitas ekonomi yang mudah dijalankan oleh masyarakat. Pada sektor ini, sumber daya lokal digunakan sebagai faktor utama dalam kegiatan produksi, skala kegiatannya lebih kecil dan lebih berfokus pada tenaga kerja dalam kegiatan produksinya dengan menggunakan teknologi yang cenderung sederhana. Keterampilan atau ilmu yang diperoleh dari pengalaman atau pendidikan informal, kebijakan pemerintah justru tidak berdampak langsung bagi pengusaha di sektor ini (Manning 1996). Tenaga kerja dapat membantu dalam proses produksi maupun melayani konsumen sehingga permintaan konsumen dapat terpenuhi. Hal ini karena pengusaha tidak bisa bekerja sendiri. Jika permintaan konsumen dapat terpenuhi dengan maksimal maka pendapatan yang diperoleh juga akan maksimal (Putra dan Sudirman 2015). Oleh sebab itu, tenaga kerja pada usaha tahu memiliki koefisien yang paling besar pada model pendapatan, karena apabila tenaga kerja pada usaha tahu meningkat atau diperbanyak maka pendapatan usaha tahu juga akan meningkat. Adapun tenaga kerja pada usaha tahu ini ialah tenaga kerja harian dengan jam kerja rata-rata, yaitu 8 jam per hari. Jumlah tenaga kerja pada setiap usaha tahu di Indonesia juga bervariasi mulai dari hanya memiliki 1 tenaga kerja hingga usaha tahu yang memiliki tenaga kerja dengan jumlah ratusan.
Selain itu, nilai p-value variabel jumlah tenaga kerja yaitu sebesar 0,000. Nilai tersebut lebih kecil dari taraf nyata 5 persen yang berarti variabel tenaga kerja memiliki pengaruh yang signifikan terhadap pendapatan. Hasil ini sesuai dengan penelitian Nayaka dan Kartika (2018) serta Ridha (2017) yang menyatakan bahwa tenaga kerja berpengaruh positif terhadap pendapatan, yaitu berarti semakin banyak tenaga kerja yang digunakan maka semakin besar pula kemungkinan jumlah produk yang dihasilkan, sehingga kemungkinan pendapatang yang diperoleh semakin besar melalui hasil penjualan produknya.

Variabel dummy kategori distribusi penjualan ke perusahaan memiliki nilai pvalue yaitu sebesar 0,136 , yang mana nilai tersebut lebih besar dari taraf nyata 5 persen. Hal ini menunjukkan bahwa variabel dummy kategori distribusi penjualan ke perusahaan tidak berpengaruh terhadap pendapatan. Adapun nilai koefisien dari variabel tersebut yaitu sebesar 0,6056. Hal ini menunjukkan bahwa apabila terjadi kenaikan penjualan ke perusahaan sebesar 1 persen, maka akan meningkatkan pendapatan sebesar 0,6056 persen. Variabel dummy kategori distribusi penjualan ke pedagang memiliki nilai koefisien yaitu sebesar 0,0070. Hal ini menunjukkan apabila terjadi peningkatan distribusi penjualan ke pedagang sebesar 1 persen, maka akan meningkatkan pendapatan usaha sebesar 0.0070 persen. Selain itu, variabel dummy kategori distribusi penjualan ke pedagang tidak berpengaruh signifikan terhadap pendapatan, hal ini terlihat dari nilai pvalue variabel tersebut yang lebih besar dari taraf nyata 5 persen $(0,951>0,05)$. Usaha tahu mitra dan non mitra lebih banyak mendistribusikan tahu ke pedagang disbanding perusahaan.

Variabel dummy alokasi pemasaran memiliki nilai koefisien sebesar 0.3936 dan berpengaruh signifikan terhadap pendapatan. bahwa pemasaran tahu di dalam kota lebih menguntungkan bagi para pelaku usaha dibandingkan memasarkan ke luar kota, karena jika memasarkan ke luar kota perlu 
biaya tambahan yang cukup besar seperti biaya pengiriman, dan para pedagang olahan tahu juga pasti lebih memilih produk tahu yang sudah ada di dalam kota, untuk meminimalkan biaya pengeluaran. Akan tetapi, walaupun alokasi pemasaran berpengaruh signifikan, usaha tahu di Indonesia masih saja kesulitan dalam memasarkan tahunya.

Hasil uji secara parsial juga menunjukkan bahwa variabel umur usaha memiliki nilai p-value sebesar 0.004, yang mana nilai tersebut lebih kecil dari taraf nyata 1 persen. Hasil ini menunjukkan bahwa terdapat pengaruh positif antara umur usaha terhadap pendapatan usaha tahu. Dengan nilai koefisien pada variabel umur usaha sebesar 0,2675 . Hal ini menunjukkan apabila semakin bertambahnya umur usaha tahu, maka akan meningkatkan pendapatan usaha tahu di Indonesia sebesar 0.2675 persen, ceteris paribus. Lama usaha menjadi sebuah penentu dari pendapatan usaha, khususnya pada usaha di sektor informal. Lama usaha merupakan waktu yang telah dijalani pelaku usaha dalam menjalankan usahanya. Lama usaha dapat menentukan pengalaman, semakin lama usaha itu beroperasi maka akan semakin baik kinerja usaha tersebut. Hasil ini sesuai dengan penelitian terdahulu yang dilakukan oleh Setiaji dan Fathuniah (2018) yang menyatakan bahwa lama usaha berpengaruh positif terhadap pendapatan.

Nilai koefisien dari variabel tingkat pendidikan sebesar 0,1294. Hal ini menunjukkan apabila semakin tinggi tingkat pendidikan pelaku usaha tahu, maka akan meningkatkan pendapatan sebesar 0,1294 persen, ceteris paribus. Akan tetapi, variabel tingkat pendidikan tidak berpengaruh signifikan terhadap pendapatan usaha tahu di Indonesia. Hal ini terlihat dari nilai p-value variabel tersebut yang lebih besar dari taraf nyata 5 persen $(0,319>0,05)$. Kinerja usaha lebih banyak dipengaruhi oleh faktor-faktor lain selain tingkat pendidikan pelaku usaha, sehingga tingkat pendidikan tidak menjadi faktor penggerak utama dalam meningkatkan kinerja usaha yaitu pendapatan. Hasil ini tidak mendukung pendapat Utari dan Dewi
(2014) bahwa tingkat pendidikan berpengaruh terhadap pendapatan.

Pada hasil estimasi model pendapatan memperoleh nilai koefisien dari variabel umur pengusaha dengan tanda negatif yaitu sebesar $-0,2574$. Hal ini menunjukkan umur pelaku usaha yang semakin bertambah akan menurunkan pendapatan usaha tahu, karena semakin bertambahnya umur maka semakin kurang produktif sehingga kinerja dalam menghasilkan produk semakin menurun. Selain itu, variabel umur pengusaha juga tidak berpengaruh signifikan terhadap pendapatan usaha tahu di Indonesia. Hal ini terlihat dari nilai $\mathrm{p}$-value variabel tersebut yang lebih besar dari taraf nyata 5 persen $(0,269>0,05)$.

Variabel dummy pelatihan memiliki nilai p-value yaitu sebesar 0,194, yang mana nilai tersebut lebih besar dari taraf nyata 5 persen. Adapun nilai koefisien variabel dummy pelatihan adalah sebesar 0,3551. Hasil ini menunjukkan bahwa pelatihan tidak berpengaruh terhadap pendapatan. Pelatihanpelatihan yang diikuti oleh usaha tahu belum bisa mempengaruhi pendapatan usaha, meskipun pelatihan yang diberikan sesuai dengan usaha yang ditekuni. Hasil ini didukung oleh penelitian Widayati (2010) bahwa program pelatihan tidak mempengaruhi pendapatan usaha.

Bahan baku berpengaruh positif signifikan terhadap pendapatan usaha tahu di Indonesia, yang mana bahan baku menjadi salah satu faktor yang dapat meningkatkan pendapatan. Hasil ini sesuai dengan penelitian yang dilakukan oleh Suartawan dan Purbadharmaja (2017) serta Nayaka dan Kartika (2018) yang mengatakan bahwa bahan baku berpengaruh positif terhadap pendapatan. Setiawan (2012) mengatakan bahwa bahan baku memiliki pengaruh yang besar terhadap peningkatan faktor produksi. Jika bahan baku sulit didapatkan maka proses produksi akan terhambat atau bahkan produsen memutuskan untuk menghentikan produksinya, begitupun sebaliknya jika bahan baku mudah didapatkan maka produksi akan ber- 
jalan lancar dan meningkat sehingga pendapatan pun ikut meningkat.

Variabel dummy modal usaha memiliki nilai koefisien sebesar 0,0820 . Hal ini menunjukkan apabila terjadi peningkatan pada penggunaan modal sendiri, maka akan meningkatkan pendapatan usaha. Namun, variabel dummy modal usaha tidak berpengaruh signifikan terhadap pendapatan. Hal ini terlihat dari nilai $p$-value variabel tersebut yang lebih besar dari taraf nyata 5 persen $(0,568>$ $0,05)$. Akan tetapi, hasil ini kurang sesuai dengan hasil penelitian dari Utari dan Dewi (2014), Suartawan dan Purbadharmaja (2017) yang mengatakan bahwa modal berpengaruh signifikan terhadap pendapatan, karena apabila modal usaha meningkat maka produksi ikut meningkat. Dengan begitu pendapatan pun ikut meningkat.

Pada hasil estimasi model pendapatan, variabel jumlah alat memiliki nilai koefisien sebesar 0,0371 . Adapun nilai $p$-value variabel jumlah alat, yaitu sebesar 0,482 yang mana nilai tersebut lebih besar dari taraf nyata 5 persen. Hal ini menunjukkan apabila terjadi kenaikan jumlah alat sebesar 1 persen, maka akan meningkatkan pendapatan sebesar 0,0371 persen, ceteris paribus. Akan tetapi, berdasarkan nilai probabilitas disimpulkan bahwa variabel jumlah alat tidak berpengaruh signifikan terhadap pendapatan. Jumlah alat yang digunakan dalam usaha guna untuk mempercepat produktivitas ini sering disebut dengan teknologi. dengan adanya alat atau teknologi tersebut dapat mempermudah tenaga kerja untuk menghasilkan sebuah produk dengan cepat. Namun, berdasarkan hasil estimasi model, alat atau teknologi yang digunakan para pelaku usaha belum bias memengaruhi kinerja usaha dalam hal ini yaitu pendapatan. Hasil ini kurang sesuai dengan hasil penelitian Utari dan dewi (2014) yang menyatakan bahwa teknologi berpengaruh positif terhadap pendapatan, sehingga semakin canggih teknologi yang digunakan, maka pendapatan UMKM akan semakin meningkat.
Pada hasil estimasi model pendapatan, diperoleh nilai koefisien dari variabel dummy koperasi, yaitu sebesar 0,2165. Hal ini menunjukkan apabila usaha tahu menjadi anggota koperasi, maka pendapatan usaha akan meningkat. Akan tetapi, variabel dummy koperasi tidak berpengaruh signifikan terhadap pendapatan, terlihat dari nilai $p$-value variabel tersebut yang lebih besar dari taraf nyata 5 persen $(0,356>0,05)$.

\section{KESIMPULAN DAN SARAN}

\section{KESIMPULAN}

Berdasarkan hasil analisis pengaruh kemitraan terhadap kinerja usaha menunjukkan bahwa kemitraan memiliki pengaruh signifikan terhadap pendapatan usaha. Dengan terjalinnya kemitraan antara usaha tahu dengan usaha lain maka dapat mengurangi kesulitan yang sering dihadapi usaha tahu agar kinerja usahanya meningkat. Selain itu, berdasarkan hasil uji beda rata-rata pendapatan antara usaha tahu yang bermitra dan usaha tahu non mitra menunjukkan bahwa terdapat perbedaan yang signifikan antara rata-rata pendapatan usaha tahu bermitra dan non mitra. Dari hasil tersebut dapat disimpulkan bahwa kemitraan memengaruhi kinerja usaha tahu di Indonesia. Dengan adanya kemitraan yang terjalin antara usaha tahu dengan usaha lain dapat meminimalkan kesulitan yang dihadapi usaha tahu serta dapat meningkatkan pendapatan usaha tahu.

Berdasarkan hasil uji $\mathrm{F}$ untuk semua variabel yaitu umur usaha, tingkat pendidikan, umur pengusaha, pemakaian bahan baku, jumlah alat, jumlah tenaga kerja, dummy modal usaha, dummy pelatihan, dummy distribusi penjualan ke perusahaan, dummy distribusi penjualan ke pedagang, dummy alokasi pemasaran, dan dummy koperasi secara bersama-sama berpengaruh signifikan terhadap pendapatan. Selanjutnya secara parsial (uji-t) diperoleh bahwa secara signifikan pendapatan dipengaruhi oleh umur usaha, pemakaian bahan baku, jumlah tenaga kerja, dan dummy alokasi pemasaran. Adapun jumlah 
tenaga kerja yang digunakan memiliki pengaruh yang paling besar terhadap pendapatan usaha tahu.

\section{SARAN}

Pelaku usaha tahu yang belum bermitra untuk memikirkan kembali keuntungan yang diperoleh jika menjalin kemitraan, karena dengan terjalinnya kerjasama dengan usaha lain dapat meminimalkan adanya kesulitan seperti kesulitan memperoleh bahan baku, kesulitan permodalan dan kesulitan dalam memasarkan produk. Kemudian untuk usaha tahu yang bermitra agar lebih mempererat hubungan kemitraannya. Pelaku usaha tahu sebaiknya lebih memperhatikan faktor inputnya yaitu bahan baku dan tenaga kerja, dengan mencari cara agar bahan baku dapat terpenuhi karena ketika bahan baku langka dan mahal, maka proses produksi akan terhambat. Kemudian para pelaku usaha sebaiknya memilih tenaga kerja yang terampil agar proses produksi dapat berjalan dengan maksimal.

\section{DAFTAR PUSTAKA}

Amstrong M. 2004. Performance Management. Jogjakarta: Tugu.

[BPS] Badan Pusat Statistik. 2015. Survey Industri Mikro dan Kecil 2015 Tahunan.

Fletcher KL. 1987. The Law of Partnership. Sidney: The Law Book Company Limited.

Hati SW, Irawati R. 2017. Faktor-faktor yang mempengaruhi Kinerja Usaha Mikro Kecil Menengah (UMKM) di Kota Batam. Jurnal Proceeding of 5 Applied Business and Engineering Conference.

Huxham C, Vangen S. 2005. Managing to collaborate: The theory and practice of collaborative advantage. New York (AS): Routledge.

[Kemenkop UKM] Kementerian Koperasi dan Usaha Kecil dan Menengah. 2018. Perkembangan Usaha Mikro dan Kecil di
Indonesia Tahun 2016-2017. Jakarta: Kementerian Koperasi dan Usaha Mikro, Kecil dan Menengah.

Louise L. 2011. Business-community partnerships: understanding the nature of partnership. Corporate Governance: The international journal of business in society. 11 (1): $29-40$.

Marco VH, Mirjam VP, Kees C. 2005. The Effects of Performance Measurements and Compensation on Motivation: an Empirical Study. De Economist. 3:303-329.

Manning C, Tadjuddin NE. 1996. Urbanisasi, Pengangguran dan dan Sektor Informal di Kota. Jakarta: Yayasan Obor Indonesia.

Mohr J, Spekman R. 1994. Characteristics of partnership success: Partnership attributes, communication behavior, and conflict resolution techniques. Strategic Management Journal. 15 (2): 135-152.

Munizu M. 2010. Pengaruh Faktor-Faktor Eksternal terhadap Kinerja Usaha Mikro dan Kecil (UMK) di Sulawesi Selatan. Jurnal Manajemen dan Kewirausahaan. 12 (1): 71-80.

Nayaka KW, Kartika IN. 2018. Pengaurh Modal, Tenaga Kerja dan Bahan Baku terhadap Pendapatan Pengusaha Industri Sanggah di Kecamatan Mengwi. Jurnal Ekonomi dan Bisnis Universitas Udayana. 7 (8): 1927-1956.

Pamungkas O. 2006. Peningkatan Kinerja Usaha melalui Strategi Kemitraan. Jurnal Bisnis Strategi. 15 (2): 47-51.

Porter, ME. 1980. Competitive Strategy Techniques for Analyzing Industrial and Competitors. New York: Free Press.

Porter ME, Kramer MR. 2002. The Competitive Advantage of Corporate Philanthropy. Harvard Business Review.

Putra IPD, Sudirman IW. 2015. Pengaruh Modal dan Tenaga Kerja terhadap Pendapatan dengan Lama Usaha sebagai Variabel Moderating. Jurnal Ekonomi 
Pembangunan Universitas Udayana. 4 (9): 1110-1139.

Purwaningsih R, Pajar DK. 2015. Analisis Faktor-Faktor Yang Mempengaruhi Kinerja Usaha Kecil Dan Menengah (UKM) Dengan Metode Structural Equation Modeling. [Thesis]. Semarang: Universitas Diponegoro.

Ridha A. 2017. Faktor-Faktor yang Mempengaurhi Pendapatan Usaha Kerajinan Tas Aceh di Desa Ulee MadenKecamatan Muara Batu Kabupaten Aceh Utara. Jurnal Samudra Ekonomi. 1 (1): 87-93.

Rudberg M, Olhager J. 2003. Manufacturing Network and Supply Chain: an Operation Strategy Perspective. Omega.

Setiaji K, Fatuniah LF. 2018. Pengaruh Modal, Lama Usaha dan Lokasi terhadap Pendapatan Pedagang Pasar Pasca Relokasi. Jurnal Pendidikan Ekonomi dan Bisnis. 6 (1): 1-14.

Suartawan IK, Purbadharmaja IB. 2017. Pengaruh Modal dan Bahan Baku terhadap Pendapatan melalui Produksi Pengrajin Patung Kayu di Kecamatan Sukawati Kabupaten Gianyar. Jurnal Ekonomi Pembangunan Universitas Udayana. 6 (9): 1628-1657.

Sudibyo B. 1997. Pengukuran Kinerja Perusahaan Dengan Balanced Scorecard: Bentuk, Mekanisme dan Prospek Aplikasinya pada BUMN. Jurnal Ekonomi dan Bisnis Islam. 12(2): 35-49.

Suryana T. 2014. Pengaruh Lingkungan Eksternal, Internal dan Etika Bisnis terhadap Kemitraan Usaha serta Implikasinya pada Kinerja Usaha Kecil di Jawa Barat. [Disertasi]. Bandung: Universitas Pasundan.

Utari T, Dewi PM. 2014. Pengaruh Modal, Tingkat Pendidikan dan Teknologi terhadap Pendapatan Usaha Mikro Kecil dan Menengah (UMKM) di Kawasan Imam Bonjol Denpasar Barat. Jurnal Ekonomi Pembangunan Fakultas Ekonomi dan Bisnis Universitas Udayana. 3 (12): 576585. 